Article

\title{
Toward Sustainable Arctic Shipping: Perspectives from China
}

\author{
Qiang Zhang ${ }^{\circledR}$, Zheng Wan * and Shanshan Fu \\ College of Transport and Communications, Shanghai Maritime University, Shanghai 201306, China; \\ qiangzhang@shmtu.edu.cn (Q.Z.); ssfu@shmtu.edu.cn (S.F.) \\ * Correspondence: mrwan@ucdavis.edu
}

Received: 21 September 2020; Accepted: 27 October 2020; Published: 29 October 2020

\begin{abstract}
As a near-Arctic state and a shipping power, China shows great interest in developing polar shortcuts from East Asia to Europe against the background of shrinking Arctic sea ice. Due to the Arctic's historic inaccessibility and corresponding vulnerable ecosystems, Arctic shipping activities must be carried out sustainably. In this study, a content analysis method was adopted to detect Chinese perspectives toward sustainable Arctic shipping based on qualitative data collected from the websites of several Chinese government agencies. Results show that, first, China emphasizes the fundamental role played by scientific expeditions and studies in developing Arctic shipping routes. Second, China encourages its shipping enterprises to conduct commercial and regularized Arctic voyages and intends to strike a good balance between shipping development and environmental protection. Third, China actively participates in Arctic shipping governance via extensive international cooperation at the global and regional levels. Several policy recommendations on how China can develop sustainable Arctic shipping are proposed accordingly.
\end{abstract}

Keywords: sustainability; Arctic shipping; governance; China

\section{Introduction}

Arctic sea ice is undergoing an extraordinary transition from generally thick multi-year sea ice to seasonal sea ice that is younger and less thick because of global warming [1]. Specifically, the volume of Arctic sea ice has declined by 75\% since 1979 [1]. The reduction in Arctic sea ice provides potential business opportunities for the international shipping industry. It is predicted that about $5 \%$ of the world's future shipping trade could be redeployed to utilize Arctic shipping routes by 2030 [2]. However, increasing shipping activities will significantly impact Arctic marine ecosystems and coastal communities with high confidence [3]. Those ship-based environmental impacts include accidental discharge of oil or toxic chemicals, regular discharges to water, emissions to air, sound and noise disturbance, vessel strikes on marine mammals, light disturbance, and introduction of invasive species [4]. Therefore, shipping activities must be conducted in a sustainable and environment-friendly manner in the Arctic area, where the ecosystems are especially vulnerable to potential impacts from ships [5].

In general, anthropogenic impacts caused by increased human activities will certainly result in greater risks in the Arctic [6]. Despite the presence of governance arrangements applicable to human activities [7], emerging needs for Arctic governance are generated by a continuous increase in human activities including commercial freight shipping and ship-based adventure tourism [8]. Regarding the governance of Arctic shipping, the United Nations Convention on the Law of the Sea (UNCLOS) provides a fundamental framework, under which certain key concepts are clearly regulated, such as the right of innocent passage in the territory seas, freedom of high seas enjoyed by ships, and the rights and duties of the coastal states and the other states in the exclusive economic zones. Nevertheless, 
governance of Arctic marine resources including shipping routes is still falling short of ideally matching management in reasonable scale and scope [9]. Given the potential negative impacts from ships on the Arctic marine environment, more elaborated and integrated shipping governance is needed to improve the Arctic's adaptive capacity for increased shipping activities. The Arctic should be governed sustainably with an ecosystem-based governance approach [10]. In a practical context, the approach of ecosystem-based governance has significant potential for ensuring the sustainability of the Arctic marine environment, and thereby minimizing risk [11]. According to the extensive Arctic shipping discourse, actors involved in Arctic shipping generally agree on the principal possibility that shipping can be sustainable in the Arctic [12].

The development of environmental, political, and economic globalization draws China's interest in the Arctic against the background of dramatic economic growth in past decades [13]. As one of the world's top three shipowning countries, China owns $10.51 \%$ of the world's fleet ranked by dead-weight tonnage [14]. In the recent decade, China has shown great interest in developing Arctic shipping routes to shorten the sailing distance from East Asia to Europe. Compared to the traditional route through the Suez Canal, Arctic shipping shortcuts have potential economic competitiveness because of the considerable savings in energy cost and transit time [15,16]. In the summer of 2013, the cargo ship Yong Sheng, operated by China's largest shipping company, COSCO Shipping, completed the first Chinese commercial voyage from China to Western Europe via the Northern Sea Route (NSR) [17]. In addition to the NSR, the Northwest Passage (NWP) along the northern coast of North America is also an optional trans-Arctic shipping route [4]. Since the first commercial trial voyage in 2013, COSCO Shipping has conducted a few trans-Arctic voyages, with the goal of normalizing Arctic shipping with regularized operation [15]. To better participate in Arctic affairs and expound the basic positions on these affairs, the Chinese government issued the white paper China's Arctic Policy in January 2018, in which China's views on the current Arctic governance framework and its intended actions on the improvement of Arctic governance are presented [18]. According to the mentioned white paper, "sustainability" is listed as one of the most important basic principles that China will follow to reach its policy goals regarding the Arctic [19]. China claims that the country is devoted to developing and using Arctic shipping routes sustainably. Therefore, the basic positions China holds on sustainable Arctic shipping and the manner of its engagement in Arctic shipping activities need to be understood comprehensively.

The current study performs content analysis to examine China's official perspectives toward sustainable Arctic shipping. The main contributions of this study are threefold. First, it fills a research gap by presenting China's major views on how to promote the sustainability of Arctic shipping based on substantial qualitative data from the websites of several Chinese government agencies. Second, a content analysis approach is introduced into the field of Arctic studies, thus enriching the research methods in this domain. Third, several policy recommendations on the sustainable development of Arctic shipping are proposed.

The remainder of this study is organized as follows. The detailed methodological steps of how we conducted the content analysis are presented in Section 2. Section 3 illustrates the statistical results of our analysis. The interpretations are made in Section 4 to articulate China's main views on sustainable Arctic shipping. Section 5 concludes with some policy recommendations.

\section{Methodology}

Except for the white paper issued in January 2018, China rarely releases formal specialized policies on the Arctic. Limited data exist about China's official governance perspectives toward Arctic shipping. To overcome the insufficiency of formalized policy texts, we chose to build a research dataset for our study by collecting official online releases, including news, interviews, and speeches from Chinese government websites, namely, the Chinese central government website (http://www.gov.cn/) as well as the websites of the Ministry of Foreign Affairs (MOFA) (https://www.fmprc.gov.cn/) and the Ministry of Transport (MOT) (http://www.mot.gov.cn/). We admit that there exist other government agencies 
such as the State Oceanic Administration (SOA) that might be relevant to our research. However, we argue that the three mentioned websites can provide enough data for our research. These websites were selected for three reasons. First, the releases from the official websites are generally posted responsibly and rigorously, which to a great extent can reflect the official attitudes to specific affairs. Second, the website of the Chinese central government actually functions as an information hub collecting important official releases from the various ministries and the agencies governed by the State Council. Therefore, the website by itself can provide a large amount of information regarding Arctic affairs. It is worth mentioning that a number of records collected from the Chinese central government website are originally from the SOA, particularly those records on Chinese scientific expeditions in the Arctic. Third, Arctic shipping as an international transport mode is related to the use of passages within high seas and the coastal States' territorial seas, contiguous zones, and exclusive economic zones, among others. It is not only a matter of transportation, but also in the scope of international relations. In China, MOT is the authority in the domain of shipping administration. It plays an important role in encouraging Chinese shipping enterprises to conduct commercial voyages in the Arctic. Comparatively, MOFA is responsible for dealing with foreign affairs. It is very necessary for China to promote international cooperation with other countries, especially the Arctic States, when developing Arctic shipping. Therefore, the MOT and MOFA websites were selected.

Due to the qualitative nature of our research dataset, we adopted a content analysis method to interpret and understand China's official views and intended actions on Arctic shipping governance. Content analysis is widely used to examine information from recorded communication sources, such as books, newspapers, speeches, and interviews [20]. According to the author of [20], content analysis has advantages on scrutinizing media communications, and it can provide numerous insights into the trends in society. In recent years, content analysis as an emerging technique has been applied by a growing number of port and shipping studies, such as [21] and [22]. The content analysis in the present study was processed as follows.

Step 1. Data Gathering. Considering that Arctic shipping affairs are very complex and have close relationships with other fields, the word "Arctic" (“北极" in Chinese), rather than the term "Arctic shipping", was searched as the keyword in the search bars on the homepages of the websites of the Chinese central government, MOT, and MOFA. By doing so, the data could be collected more broadly, which ensured that Chinese perspectives toward sustainable Arctic shipping could be detected as comprehensively as possible. As a result, 220, 74, and 51 records were gathered, respectively. There were 345 records in total. All the records were posted online before 29 February 2020, when we finished our search. Regarding the time span of the collected records, specifically, 220 records from the Chinese central government were distributed during the period from 22 September 2006 to 5 February 2020, 74 records from MOT appeared in the period from 11 July 2008 to 26 February 2020. Comparatively, the time span of the 51 records from MOFA was relatively short. The first record was posted on 17 October 2015, and the last one was on 25 June 2019.

Step 2. Data Cleaning. In this step, duplicated records were excluded. Moreover, to ensure that the remaining records were closely related to the research topic on Arctic shipping, two of our professional researchers who are familiar with Arctic affairs were designated to check the records by reading the contents of each record and determine irrelevant records to be deleted in the dataset. To form an unbiased record list, the two researchers were required to work independently and form their own lists. The two lists were then compared, and their differences were fully discussed by the research team. Finally, 229 records from the original dataset were selected, and they made up the final research dataset in the study. Among the selected records, four formal policy documents were issued by Chinese government agencies, and seven joint statements were released by China and other countries. In addition, 14 speeches were made by Chinese government officials, such as the ambassadors working in Arctic coastal countries, and 20 interviews on Arctic affairs were found, including the interview given by the captain of China's polar research vessel Xue Long (Snow Dragon) about the use of the NSR in the Arctic. 
Step 3. Data Coding. Coding the contents by categorizing them is a common method in studies using content analysis (e.g., [23,24]). In this study, a priori category coding method was adopted. Through the intensive reading and preliminary interpretation of our final selected records, the two researchers who participated in data cleaning proposed an initial list of coding categories. These categories were tested by being used to code 10 randomly chosen records in our research dataset. The coding process was carried out by three trained coders. Based on this test, the disagreements on the coding were discussed, and the categories were revised accordingly. After several rounds of the kindred tests, seven coding categories were finally determined, and the intercoder reliability was satisfactory. Table 1 shows the coding categories and their definitions. Each research record was coded and labeled with a specific category or several categories. Note that the category of "development of Arctic shipping routes", strictly speaking, should be in the scope of "Polar Silk Road". However, to indicate the contents of Arctic shipping in our dataset, we separated them from the contents regarding the Polar Silk Road initiative, and formed the "development of Arctic shipping routes" as an independent category.

Table 1. Coding categories and definitions.

\begin{tabular}{|c|c|}
\hline Category Name & Definition \\
\hline $\begin{array}{l}\text { Scientific expedition and research } \\
\text { in the Arctic (SER) }\end{array}$ & $\begin{array}{l}\text { Research activities in the Arctic, not only in the natural science domain, } \\
\text { but also in the domain of social science }\end{array}$ \\
\hline $\begin{array}{l}\text { Technical support for Arctic } \\
\text { shipping (TS) }\end{array}$ & $\begin{array}{l}\text { Development of technical equipment and maritime information systems } \\
\text { to ensure the improvement of the navigation, security, and logistical } \\
\text { capacities in the Arctic }\end{array}$ \\
\hline $\begin{array}{l}\text { Development of Arctic shipping } \\
\text { routes (DSR) }\end{array}$ & $\begin{array}{l}\text { Development plans or intentions for Arctic shipping routes, } \\
\text { participation in the shipping and port infrastructure construction, } \\
\text { and implementation of the voyages on these routes }\end{array}$ \\
\hline $\begin{array}{l}\text { Protection of Arctic } \\
\text { environment (PE) }\end{array}$ & $\begin{array}{l}\text { Control of the sources of pollution from human activities including } \\
\text { shipping, conservation of biological resources, protection of biodiversity, } \\
\text { and active measures to deal with climate change }\end{array}$ \\
\hline $\begin{array}{l}\text { Legal framework related to Arctic } \\
\text { governance (LF) }\end{array}$ & $\begin{array}{l}\text { International law and treaties that are generally or specifically } \\
\text { applicable to the governance of the Arctic, domestic laws of Arctic States } \\
\text { Cooperation with various states and international organizations in }\end{array}$ \\
\hline $\begin{array}{l}\text { International cooperation at the } \\
\text { global and regional levels (IC) }\end{array}$ & $\begin{array}{l}\text { Arctic affairs, including Arctic scientific research, governance issues, } \\
\text { environmental protection, maritime navigational security, } \\
\text { and maritime technology }\end{array}$ \\
\hline Polar Silk Road (PSR) & $\begin{array}{l}\text { Cross-cultural communication with Arctic States, foreign direct } \\
\text { investment in Arctic States, and economic cooperation in utilizing Arctic } \\
\text { resources, such as oil, gas, and minerals }\end{array}$ \\
\hline
\end{tabular}

Step 4. Statistical Analysis and Interpretations. The statistical results of the coding were presented in this step. Based on the coding results and the in-depth understanding generated during the coding process, effective interpretations were made to articulate the perspectives toward sustainable Arctic shipping from the Chinese government.

\section{Statistical Analysis Results}

Our final research dataset comprised 229 records. Figure 1 shows the distribution of the number of research records by year. Before 2010, very limited data were available from the websites of relevant Chinese government agencies because the system of the openness of government affairs was unsound at that time. In addition, the country was not heavily involved in Arctic affairs including Arctic shipping. With the improvement in government affairs openness and further involvement in the trans-regional and global issues in the Arctic, an increasing amount of media coverage on Chinese activities in the Arctic has been given on the governmental websites since 2010, when China conducted its fourth Arctic scientific expedition and created a historical record by reaching the North Pole. Notably, the number of the records in 2018 is the highest. The most important reason behind this is that China issued a 
specialized white paper on its Arctic policies for the first time, thereby drawing considerable public attention. In this white paper, China clearly elaborated its policies and positions on participating in Arctic affairs.

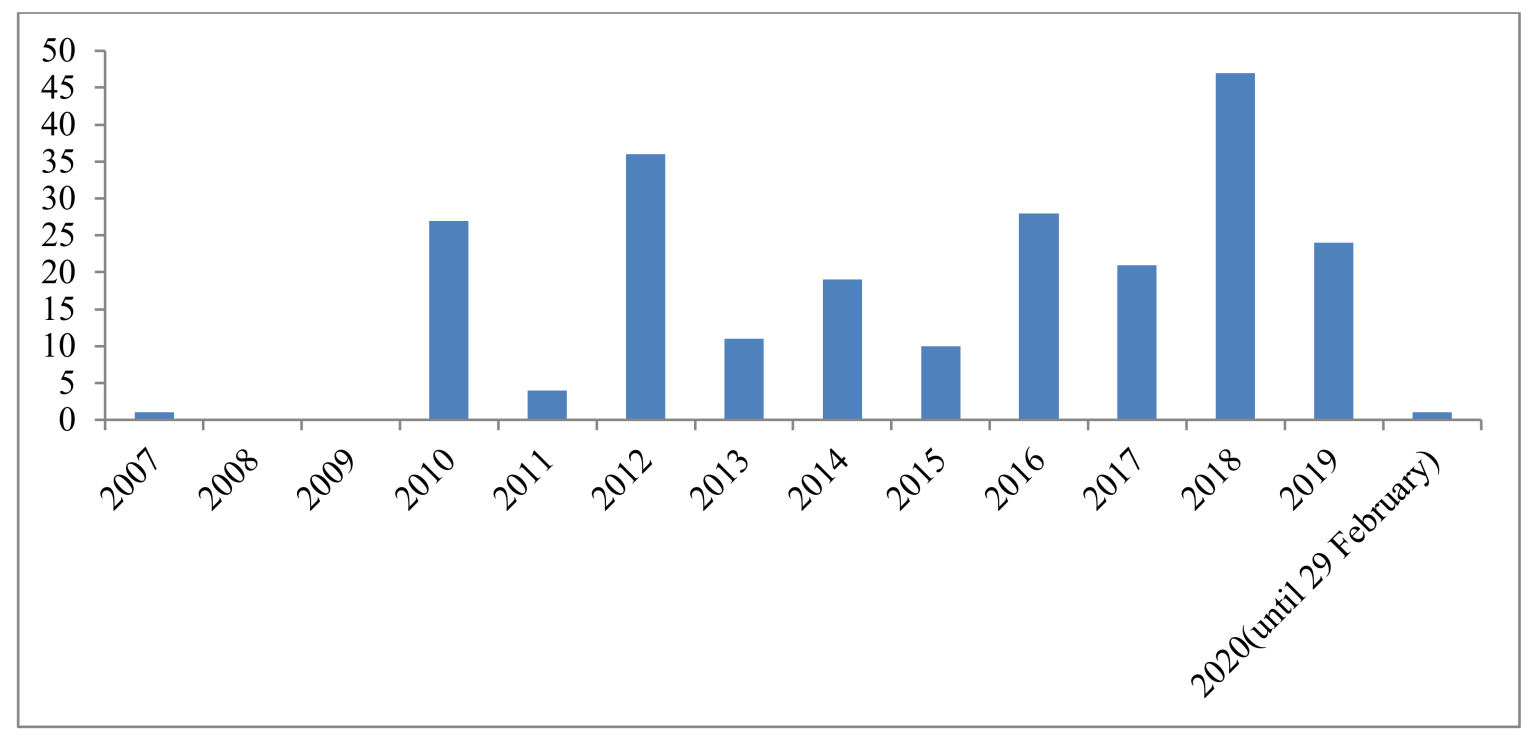

Figure 1. Number of records by year.

Table 2 presents the coding results. A total of 127 records are categorized with SER, which means that more than half $(55.5 \%)$ records are related to the Arctic research activities in our dataset. This high proportion is not hard to understand because the Chinese government has always given high priority to scientific research on the Arctic. The number of the records that are labeled with IC is also over 100, reaching 105. Thus, international cooperation is a very important measure that China has adopted to participate in Arctic affairs. The 74 DSR records show the increasing attention that China has paid to the use of shipping shortcuts in the Arctic. Due to the Arctic's special and vulnerable ecosystem, environmental protection is definitely a big concern. In the dataset, 60 records are labeled with PE accounting for $32.3 \%$ of all research records. Since China and Russia jointly proposed the PSR initiative in 2017, PSR has become a macro policy term used by China with broad aspects and rich content. Notably, economic cooperation and cross-cultural communication are two core elements of PSR. Nearly $20 \%$ of our research records are in the scope of PSR. The categories of TS and LF are coded in 32 records.

Table 2. Statistical results of the coding (number of research records, $\mathrm{N}=229$ ).

\begin{tabular}{cccc}
\hline $\begin{array}{c}\text { Category } \\
\text { Name }\end{array}$ & $\begin{array}{c}\text { Number of } \\
\text { Records in the } \\
\text { Category (Ni) }\end{array}$ & $\begin{array}{c}\text { Percent of the Categorized } \\
\text { Records in all Research } \\
\text { Records (Ni/N) }\end{array}$ & $\begin{array}{c}\text { Percent of the Categorized } \\
\text { Records in the Sum of all } \\
\text { Categorized Records (Ni/ } / \text { Ni) }\end{array}$ \\
\hline SER & 127 & $55.5 \%$ & $26.8 \%$ \\
TS & 32 & $14.0 \%$ & $6.7 \%$ \\
DSR & 74 & $32.3 \%$ & $15.6 \%$ \\
PE & 60 & $26.2 \%$ & $12.6 \%$ \\
LF & 32 & $14.0 \%$ & $6.7 \%$ \\
IC & 105 & $45.9 \%$ & $22.1 \%$ \\
PSR & 45 & $19.7 \%$ & $9.5 \%$ \\
Total & 475 & $/$ & $100 \%$ \\
\hline
\end{tabular}

Because of the content comprehensiveness of our research records, 152 of 229 records are labeled with two or more categories. Table 3 shows the numbers of records with different numbers of categories. Most of these records are labeled with two categories, accounting for $40.2 \%$ of all research records. These comprehensive records with several categories provide us a great opportunity to detect the 
potential inner relations between coding categories. Table 4 presents the numbers of the co-occurrences of two specific categories. An explanation needs to be given here. If a record is labeled with more than two categories, then each pair of two specific categories is counted. For example, if a record has four categories, namely, SER, DSR, PE, and IC, then six pairs "SER-DSR", "SER-PE", "SER-IC", "DSR-PE", "DSR-IC", and "PE-IC" are included. For each pair, the sequence of categories makes no difference (e.g., "SER-DSR" is the same as "DSR-SER"). According to Table 4, "PSR-IC" as the most used pair is identified in 44 records, which to a certain extent indicates that international cooperation has a close relation with the PSR initiative. In fact, Cooperating with Arctic States is a basic position that China holds to build PSR [19]. With regard to Arctic shipping, "DSR-SER" and "DSR-IC" are found in 34 records. These two popularly used pairs show that China emphasizes Arctic scientific research and international cooperation in developing Arctic shipping routes. Undoubtedly, environmental protection is essential for sustainable Arctic shipping. Furthermore, 23 pairs of "DSR-PE" are identified. Hence, the concern about the protection of Arctic ecosystems is generally embedded in the Chinese process of developing shipping routes in the Arctic. Comparatively, only a small number of pairs of "DSR-LF" are found because the legal framework governing the Arctic is relatively stable. Further discussions on Arctic shipping governance are presented in Section 4.

Table 3. Number of the records labeled with two or more categories.

\begin{tabular}{ccccccc}
\hline & \multicolumn{7}{c}{ Number of Categories } & $\mathbf{7}$ \\
& $\mathbf{2}$ & $\mathbf{3}$ & $\mathbf{4}$ & $\mathbf{5}$ & $\mathbf{6}$ & $\mathbf{7}$ \\
\hline Number of records & 92 & 39 & 12 & 6 & 1 & 2 \\
Proportion of all records $(\mathrm{N}=229)$ & $40.2 \%$ & $17.0 \%$ & $5.2 \%$ & $2.6 \%$ & $0.4 \%$ & $0.9 \%$ \\
\hline
\end{tabular}

Table 4. Number of the co-occurrences of two specific categories.

\begin{tabular}{cccccccc}
\hline & SER & TS & DSR & PE & LF & IC & PSR \\
\hline \multirow{2}{*}{ SER } & - & 16 & 34 & 41 & 11 & 32 & 5 \\
& 16 & $(6.99 \%)$ & $(14.85 \%)$ & $(17.90 \%)$ & $(4.80 \%)$ & $(13.97 \%)$ & $(2.18 \%)$ \\
TS & $(6.99 \%)$ & - & 17 & 10 & 5 & 6 & 3 \\
& 34 & 17 & $(7.42 \%)$ & $(4.37 \%)$ & $(2.18 \%)$ & $(2.62 \%)$ & $(1.31 \%)$ \\
DSR & $(14.85 \%)$ & $(7.42 \%)$ & - & 23 & 9 & 34 & 19 \\
& 41 & 10 & 23 & $(10.04 \%)$ & $(3.93 \%)$ & $(14.85 \%)$ & $(8.30 \%)$ \\
PE & $(17.90 \%)$ & $(4.37 \%)$ & $(10.04 \%)$ & - & 17 & 29 & 13 \\
& 11 & 5 & 9 & 17 & - & 21 & 9 \\
LF & $(4.80 \%)$ & $(2.18 \%)$ & $(3.93 \%)$ & $(7.42 \%)$ & - & $(9.17 \%)$ & $(3.93 \%)$ \\
& 32 & 6 & 34 & 29 & 21 & - & 44 \\
IC & $(13.97 \%)$ & $(2.62 \%)$ & $(14.85 \%)$ & $(12.66 \%)$ & $(9.17 \%)$ & - & $(19.21 \%)$ \\
& 5 & 3 & 19 & 13 & 9 & 44 & - \\
PSR & $(2.18 \%)$ & $(1.31 \%)$ & $(8.30 \%)$ & $(5.68 \%)$ & $(3.93 \%)$ & $(19.21 \%)$ & \\
& &
\end{tabular}

Note: The percentage presented in the parenthesis is calculated by dividing the number of the co-occurrences by all the research records of 229 .

\section{China's Views on Sustainable Arctic Shipping}

Based on the reading and coding of our qualitative data, we can make effective interpretations by presenting the main thoughts of the data to reveal China's main perspectives toward sustainable Arctic shipping. Although a specific meaning pertaining to the concept of "sustainable Arctic shipping" is not discussed explicitly, neither in the political domain nor in academia [12], the concrete moves toward the sustainable development of Arctic shipping should be discussed. In this section, the interpretations are delivered from three aspects, namely, Arctic scientific research, shipping operation, and governance. 


\subsection{The Fundamental Role of Arctic Scientific Research}

According to SCIO [19], improvements in the capacity and capability of Arctic scientific research facilitate a further understanding of the Arctic, which can further create favorable conditions for the protection, development, and governance of the Arctic. As the least sampled components of the world's oceans, many areas of the Arctic Ocean have few recorded soundings, which implies that Arctic navigation is lacking in basic marine information [4]. Therefore, exploring the ocean and charting its hydrography are very important for the safety of shipping activities in the Arctic. Both the NSR and NWP are in the geographic scope of numerous Arctic coastal seas covered by drifting or landfast sea ice seasonally, which creates navigational difficulties for ice-breaking ships, let alone less capable ships [25]. From the practice of ship transits that are conducted by China, scientific expeditions play a fundamental role in developing Arctic shipping routes. Investigating the Arctic marine environment and collecting relevant information are always emphasized by Arctic researchers. Table 5 presents some of the main research topics of China's Arctic scientific expeditions that have relevance with sustainable Arctic shipping issues in the recent decade. These research studies are identified as shipping-related ones, mainly because they focus on the Arctic marine environment, which can deepen the understanding of the Arctic Ocean and further help to better develop Arctic shipping routes by mitigating their impacts on Arctic marine ecosystems. For example, one of the research studies undertaken during China's ninth Arctic scientific expedition in 2018 was on the marine environment and ecological characteristics of the key waters (e.g., Chukchi Sea) of the Arctic Ocean. The outcomes of this research can to some extent help crews improve their vessels' environmental performance when sailing in those key waters by making the navigation match their characteristics.

Table 5. Shipping-related research topics of China's Arctic scientific expeditions.

\begin{tabular}{|c|c|c|}
\hline & Time & Shipping-Related Research Topics \\
\hline No.4 & 1 July 2010-20 September 2010 & $\begin{array}{l}\text { Mechanism of rapid change of Arctic sea ice; responses of Arctic } \\
\text { marine ecosystems to rapid changes of sea ice }\end{array}$ \\
\hline No.5 & 2 July 2012-27 September 2012 & $\begin{array}{l}\text { Key elements in the changing process of Arctic ocean } \\
\text { environment and its sea-ice-air system }\end{array}$ \\
\hline No.6 & 11 July 2014-23 September 2014 & Rapid change of the Arctic \\
\hline No.7 & 11 July 2016-26 September 2016 & $\begin{array}{l}\text { Pattern of Arctic sea ice melting; underwater acoustic } \\
\text { communication and navigation; characteristics of Arctic } \\
\text { meteorological elements; Arctic Ocean acidification }\end{array}$ \\
\hline No.8 & 20 July 2017-10 October 2017 & $\begin{array}{l}\text { Conditions of Arctic shipping routes; floating garbage and } \\
\text { microplastics in the Arctic marine environment; Arctic Ocean } \\
\text { acidification }\end{array}$ \\
\hline No.9 & 20 July 2018-26 September 2018 & $\begin{array}{l}\text { Marine environment and ecological characteristics of the key } \\
\text { waters (e.g., Chukchi Sea) of the Arctic Ocean }\end{array}$ \\
\hline No.10 & 10 August 2019-27 September 2019 & $\begin{array}{l}\text { Composition and community structure of biological species in } \\
\text { key Arctic waters }\end{array}$ \\
\hline
\end{tabular}

Note: The first three Arctic scientific expeditions are not covered by our research records. Hence, they are not presented here.

Since 2016, China has changed the frequency of its Arctic expeditions from once every two years to once a year. Hence, China gives great importance to Arctic research. These scientific works provide necessary and valuable information for Arctic shipping. More specifically, the fifth Chinese Arctic expedition in 2012 conducted a historical voyage on the NSR, marking the first time that a Chinese vessel sailed from Asia to Europe via the Arctic. The total voyage of the research vessel Xue Long on the NSR was 2894 nautical miles with a sailing time of over 270 hours [26], which directly promoted the accumulation of navigational experience for future Chinese Arctic shipping. Benefiting from the mentioned experience, the cargo vessel Yong Sheng from COSCO Shipping completed the first Chinese commercial voyage from Taicang to Rotterdam through the NSR in 2013. Moreover, in 2014, the Chinese national Maritime Safety Administration (MSA) officially released the Navigational guide for the NSR in the Arctic to comprehensively provide all-round information for Chinese vessels, such as nautical charts, 
analysis of sea ice, and meteorological conditions. Sequentially, in 2017, the Communication guide for the NSR in the Arctic was published by MSA to illustrate the distribution and service of main radio stations along the NSR. These guides can effectively help Chinese commercial vessels improve their safety when conducting Arctic voyages. In addition to the navigational information, the development of shipping-related technical equipment and the abatement of ship-based environmental impacts are also driven by Arctic scientific research. For example, a sea fog visibility profiler was tested and used during the ninth Chinese Arctic expedition, and this profiler can detect the absorption of solar radiation by sea fog and calculate the visibility of an observation area on shipping routes [27]. Notably, the research on Arctic microplastic pollution and ocean acidification draws much attention from China for the control of ships' emissions. However, it is worth noting that although Arctic scientific research can deepen the understanding of the Arctic, it may take a long time for those research outcomes to be finally transformed into the practice of sustainable Arctic shipping. Moreover, scientific expeditions themselves in the Arctic need to be conducted in a sustainable manner.

\subsection{Commercial and Regularized Operation of Arctic Shipping}

In recent years, the increasing awareness of the need to improve Arctic shipping has been an underlying assumption behind many countries' decisions in the Arctic [12]. In China, the government emphasizes the development of Arctic shipping routes because of their immense economic potential. In light of China's Arctic Policy [19], the commercial and regularized operation of Arctic shipping has been clearly listed as a specific goal, and China claims that such an operation should proceed sustainably on the condition of properly and reasonably protecting the Arctic's eco-environment. China is believed to continue to encourage its enterprises to participate in the shipping and port infrastructure construction for these shortcuts and conduct commercial voyages, and it intends to strike a good balance between Arctic shipping development and environmental protection. Table 6 shows the commercial voyages that were conducted by COSCO Shipping from 2013 to 2019. Hence, Chinese commercial and regularized shipping operation is emerging and is well enhanced. According to the comparative analysis presented by the authors of [15], greenhouse gas emissions (e.g., $\mathrm{CO}_{2}, \mathrm{CH}_{4}$, and $\mathrm{N}_{2} \mathrm{O}$ ) and ship-based air pollutant emissions (e.g., $\mathrm{NO}_{\mathrm{x}}, \mathrm{CO}$, and $\mathrm{SO}_{\mathrm{x}}$ ) can be reduced by roughly $27 \%$ per loop on the NSR compared with the route via the Suez Canal. Although the use of Arctic shipping shortcuts shows great potentials in reducing ship-based emissions, it is noted that, under the current technical conditions, a large-scale commercial and regularized Arctic shipping operation may harm the Arctic environment by ship accidents such as collisions, groundings, etc.

Table 6. Commercial trans-Arctic voyages conducted by COSCO Shipping (2013-2019).

\begin{tabular}{|c|c|c|c|c|c|}
\hline Year & Name of Vessel & Port of Departure & Departure Date & Port of Destination & Arrival Date \\
\hline 2013 & Yong Sheng & Taicang (China) & 15 August & Rotterdam (Netherlands) & 10 September \\
\hline \multirow[b]{2}{*}{2015} & Yong Sheng & Jiangyin (China) & 22 July & Varberg (Sweden) & 17 August \\
\hline & Yong Sheng & Hamburg (Germany) & 4 September & Pusan (South Korea) & 28 September \\
\hline \multirow{7}{*}{2016} & Yong Sheng & Tianjin (China) & 16 July & Glasgow (United Kingdom) & 13 August \\
\hline & Xia Zhi Yuan 6 & Tianjin (China) & 27 July & Sabetta (Russia) & 24 August \\
\hline & Tian Xi & Kotka (Finland) & 5 August & Qingdao (China) & 3 September \\
\hline & Xiang He Kou & Sabetta (Russia) & 23 August & Qingdao (China) & 17 September \\
\hline & Xiang Yun Kou & Qingdao (China) & 29 August & Sabetta (Russia) & 21 September \\
\hline & Yong Sheng & Sheerness (United Kingdom) & 8 September & Dalian (China) & 3 October \\
\hline & Lian Hua Song & Lian Yungang (China) & 1August & Esbjerg (Denmark) & 31 August \\
\hline \multirow{4}{*}{2017} & $\mathrm{Da} A \mathrm{An}$ & Tianjin (China) & 22August & Cuxhaven (Germany) & 14 September \\
\hline & Tian Le & North Fjord (Norway) & 2 September & Tomakomai (Japan) & 20 September \\
\hline & Tian Jian & Lian Yungang (China) & 31 August & Esbjerg (Denmark) & 24 September \\
\hline & Tian Fu & Grenaa (Denmark) & 5 September & Shanghai (China) & 29 September \\
\hline \multirow{8}{*}{2018} & Tian Hui & Emden (Germany) & 5 July & Tomakomai (Japan) & 11 August \\
\hline & Tian You & Da Feng (China) & 18 July & Harnosand (Sweden) & 30 August \\
\hline & Tian Jian & Helsinki (Finland) & 27 July & Qingdao (China) & 31 August \\
\hline & Tian En & Lian Yungang (China) & 4 August & Rouen (France) & 5 September \\
\hline & Tian Qi & Helsinki (Finland) & 17 August & Qingdao (China) & 18 September \\
\hline & Tian Lu & Phu My (Vietnam) & 31 August & Hull (United Kingdom) & 1October \\
\hline & Tian Hui & Lian Yungang (China) & 20 September & Oskarshamn (Sweden) & 15 October \\
\hline & Tian You & Helsinki (Finland) & 22 September & Guangzhou (China) & 24 October \\
\hline
\end{tabular}


Table 6. Cont.

\begin{tabular}{cccccc}
\hline Year & Name of Vessel & Port of Departure & Departure Date & Port of Destination & Arrival Date \\
\hline & Tian En & Taicang (China) & 20 July & Gavle (Sweden) & 17 August \\
Da Tai & Taicang (China) & 31 July & Gavle (Sweden) & 27 August \\
& Tian Xi & Helsinki (Finland) & 19 August & Qingdao (China) & 16 September \\
& Tian You & Shanghai (China) & 26 August & Hamburg (Germany) & 20 September \\
& Tian Hui & Jiangyin (China) & 30 August & Gdynia (Poland) & 26 September \\
& Da Xiang & Hamburg (Germany) & 2 September & Dalian (China) & 27 September \\
& Tian Qi & St. Petersburg (Russia) & 6 September & Phu My (Vietnam) & 9 October \\
& Tian En & Helsinki (Finland) & 13 September & Tomakomai (Japan) & 8 October \\
Da Tai & Ust-Luga (Russia) & 17 September & Rizhao (China) & 20 October \\
\hline
\end{tabular}

Source: Authors' own compilation based on [28] and news from COSCO Shipping.

\subsection{Active Participation in Arctic Shipping Governance}

China is dedicated to the improvement and complementation of the Arctic governance regime [19]. It is worth noting that Arctic governance should be a holistic, integrative, and adaptive ecosystem-based system with trans-boundary dimensions, because of the complexities in the Arctic [10]. Shipping governance is actually one of the dimensions of Arctic governance. For China, in a broader sense, it considers that the Charter of the United Nations (i.e., UN Charter) and the UNCLOS are the core elements of the basic legal framework governing Arctic shipping [19]. In more concrete terms, China respects the leadership of the International Maritime Organization (IMO) as the global standard-setting authority for the safety, security, and environmental performance of international shipping and recognizes the active role that IMO plays in formulating navigational rules for Arctic shipping. At the current stage, actively participating in Arctic shipping governance is China's action strategy not only at the global level, but also at the regional level.

More specifically, China upholds the authority of IMO's regulatory framework governing Arctic shipping and plays a constructive role in related IMO work. The International Code for Ships Operating in Polar Waters (i.e., Polar Code), adopted by IMO and entered into force on 1 January 2017, facilitates the enhancement of ship operations' robustness in Arctic waters [29]. The Polar Code, as a mandatory regulation under both the International Convention for the Safety of Life at Sea (SOLAS) and the International Convention for the Prevention of Pollution from Ships (MARPOL), covers the full range of shipping-related matters relevant to ships operating, such as ship equipment, rescue, and environmental protection in Arctic and Antarctic waters. As an A-level council member state in IMO, China has promoted the formulation, enforcement, and implementation of the Polar Code. Recently, at the 7th session of IMO's Sub-Committee on Pollution Prevention and Response (PPR) held in February 2020, the committee agreed upon draft amendments to MARPOL Annex I to introduce a prohibition on the use and carriage of heavy fuel oil as marine fuel by vessels in Arctic waters on and after 1 July 2024 [30], which undoubtedly will do much good to the protection of the Arctic marine environment. As an observer to the Arctic Council, China recognizes the Council as an important intergovernmental forum on Arctic issues regarding sustainable development and environmental protection, and actively participates in the various works of the Council including its subordinate working groups (e.g., Arctic Monitoring and Assessment Programme, Protection of the Arctic Marine Environment) [19]. In the shipping-related domain, the Arctic States have reached two legally binding agreements, namely, the Arctic Search and Rescue Agreement and the Arctic Oil Spill Preparedness and Response Agreement, under the Arctic Council framework, which shows the importance of regional cooperation [5]. In addition to the Arctic Council, China also supports cooperative platforms such as "Arctic Frontiers", "The Arctic: Territory of Dialogue", and "The Arctic Circle" in promoting cooperation among all Arctic stakeholders in Arctic governance. Comparatively speaking, regional actions on Arctic shipping governance should be more heavily emphasized; this is mainly because Arctic issues including sustainable shipping development generally have local and regional characteristics [5]. 
Except for the active participation at the global and regional levels, China also emphasizes international cooperation on Arctic affairs, including shipping issues at the bilateral and multilateral levels with Arctic and non-Arctic States. For instance, China and Iceland signed a cooperative framework agreement on Arctic issues in 2012, which was the first intergovernmental agreement between China and an Arctic State in the domain of Arctic cooperation. Moreover, since 2016, China, South Korea, and Japan have jointly established a high-level trilateral dialogue mechanism on Arctic affairs to deepen the cooperation in Arctic scientific research and commercial development, among others.

\section{Conclusions}

As a near-Arctic nation, China becomes an important stakeholder with many involvement opportunities in Arctic affairs. Due to the huge economic potentials of Arctic shipping routes, China has manifested a great interest in developing relevant routes to shorten the sailing distance from the Far East to Northern and Western Europe. China is devoted to developing Arctic shipping sustainably because of the fragile ecosystems in the area. This paper focused on the perspectives of the Chinese government toward sustainable Arctic shipping. Content analysis was adopted to analyze the qualitative data collected from the websites of several Chinese government agencies. From the statistical results of the content analysis, the development of Arctic shipping routes has close relationships with scientific research activities, environmental protection, and international cooperation, among others. With regard to China's major views on sustainable Arctic shipping, three perspectives can be summarized. First, China emphasizes the fundamental role that Arctic studies play in developing Arctic shipping routes. Scientific expeditions provide necessary marine information and navigational experience for the safety of commercial vessels. Second, China encourages its shipping enterprises to conduct commercial and regularized Arctic voyages, and believes that a balance can be struck between shipping development and environmental protection. Third, actively participating in Arctic shipping governance is China's action strategy at the global and regional levels. On the one hand, China supports IMO's role in formulating navigational rules for Arctic shipping. On the other hand, it recognizes and integrates itself into regional intergovernmental forums on Arctic issues.

Based on the in-depth analysis, some policy recommendations are further proposed for China on the development of sustainable Arctic shipping, which we believe are also applicable to other countries involved in Arctic affairs. To start with, Arctic expeditions should be conducted properly and sustainably. With the increasing attraction of the Arctic, a rising number of people from the general public, in addition to professional scientists, explore the Arctic in the name of tourism or popular science. Because of the lack of sufficient marine information, those expeditions may harm the Arctic environment by unsustainable manners, such as the improper disposal of waste. It is good to see that China issued the Regulation on Administrative Licensing for Arctic Expeditions in 2017 to reasonably carry out relevant activities of Arctic exploration. All parties should strictly abide by international maritime conventions, especially those navigational rules governing Arctic shipping. The flag states of vessels that are sailing in the Arctic should fully meet their obligations under conventions and emphasize the effective supervision of ships. Arctic States as port states should take reasonable and necessary measures to conduct Port State Control (PSC) inspections. Finally, international cooperation at the global and regional levels should be further advocated. Various stakeholders, such as governmental, intergovernmental, and non-governmental organizations, shipowners, and scientists, need to actively participate in cooperative actions on sustainable Arctic shipping.

Author Contributions: Conceptualization, methodology, data curation, formal analysis and writing—original draft preparation, Q.Z.; writing - review and editing and supervision, Z.W.; visualization and project administration, S.F. All authors have read and agreed to the published version of the manuscript.

Funding: This research was funded by the Key Soft Science Research Project of Shanghai Science and Technology Committee (20692107600 \& 20692107100) and the National Natural Science Foundation of China (51709168).

Acknowledgments: We would like to thank the two anonymous reviewers for their constructive comments. 
Conflicts of Interest: The authors declare no conflict of interest.

\section{References}

1. Arctic Monitoring and Assessment Programme (AMAP). AMAP Climate Change Update 2019: An Update to Key Findings of Snow, Water, Ice and Permafrost in the Arctic (SWIPA) 2017. Available online: https: //www.amap.no/documents/download/3295/inline (accessed on 23 November 2019).

2. Bekkers, E.; Francois, J.F.; Rojas-Romagosa, H. Melting ice caps and the economic impact of opening the Northern Sea Route. Econ. J. 2016, 128, 1095-1127. [CrossRef]

3. International Panel on Climate Change (IPCC). Summary for Policymakers. In IPCC Special Report on the Ocean and Cryosphere in a Changing Climate. 2019. Available online: https://www.ipcc.ch/srocc/chapter/ summary-for-policymakers/ (accessed on 2 March 2020).

4. Arctic Council. Arctic Marine Shipping Assessment 2009 Report. 2009. Available online: https://oaarchive. arctic-council.org/handle/11374/54 (accessed on 23 November 2019).

5. Zhang, Q.; Wan, Z.; Hemmings, B.; Abbasov, F. Reducing black carbon emissions from Arctic shipping: Solutions and policy implications. J. Clean. Prod. 2019, 241, 118261. [CrossRef]

6. Holland, G. The Arctic Ocean-The management of change in the northern seas. Ocean Coast. Manag. 2002, 45, 841-851. [CrossRef]

7. Young, O.R. Building an international regime complex for the Arctic: Current status and next steps. Polar J. 2012, 2, 391-407. [CrossRef]

8. Young, O.R. Governing the Arctic Ocean. Mar. Policy 2016, 72, 271-277. [CrossRef]

9. Fernandez, L.; Kaiser, B.; Moore, S.; Vestergaard, N. Introduction to special issue: Arctic marine resource governance. Mar. Policy 2016, 72, 237-239. [CrossRef]

10. Platjouw, F. Dimensions of transboundary legal coherence needed to foster ecosystem-based governance in the Arctic. Mar. Policy 2019, 110, 103666. [CrossRef]

11. Johannsdottir, L.; Cook, D. Systemic risk of maritime-related oil spills viewed from an Arctic and insurance perspective. Ocean Coast. Manag. 2019, 179, 104853. [CrossRef]

12. Keil, K. Sustainability understandings of Arctic shipping. In The Politics of Sustainability in the Arctic: Reconfiguring Identity, Space, and Time; Gad, U.P., Strandsbjerg, J., Eds.; Routledge: Abington, UK, 2018.

13. Bertelsen, R.G.; Gallucci, V. The return of China, Post-Cold War Russia, and the Arctic: Changes on land and at sea. Mar. Policy 2016, 72, 240-245. [CrossRef]

14. United Nations Conference on Trade and Development (UNCTAD). Review of Maritime Transport 2019. Available online: https://unctad.org/en/PublicationsLibrary/rmt2019_en.pdf (accessed on 25 November 2019).

15. Wan, Z.; Ge, J.; Chen, J. Energy-saving potential and an economic feasibility analysis for an Arctic route between Shanghai and Rotterdam: Case study from China's largest container sea freight operator. Sustainability 2018, 10, 921. [CrossRef]

16. Liu, M.; Kronbak, J. The potential economic viability of using the Northern Sea Route (NSR) as an alternative route between Asia and Europe. J. Transp. Geogr. 2010, 18, 434-444. [CrossRef]

17. World Maritime News. Spotted: Yong Sheng Starts 3rd Arctic Run. 2016. Available online: https://worldmaritimenews.com/archives/197540/spotted-yong-sheng-starts-3rd-arctic-run/ (accessed on 2 March 2020).

18. Ma, X. China's Arctic policy on the basis of international law: Identification, goals, principles and positions. Mar. Policy 2019, 100, 265-276. [CrossRef]

19. State Council Information Office of the People's Republic of China (SCIO). China's Arctic Policy. 2018. Available online: http://english.www.gov.cn/archive/white_paper/2018/01/26/content_281476026660336.htm. (accessed on 2 March 2020).

20. Lac, A. Content analysis. In Encyclopedia of Adolescence, 2nd ed.; Levesque, R.J.R., Ed.; Springer International: Cham, Switzerland, 2016; pp. 1-5.

21. Brooks, M.R. A new direction or stay the course? Canada's port-specific challenges resulting from the port reform program of the 1990s. Res. Transp. Bus. Manag. 2017, 22, 161-170. [CrossRef]

22. Rehmatulla, N.; Smith, T.; Wrobel, P. Implementation barriers to low carbon shipping. In Proceedings of the Low Carbon Shipping Conference, London, UK, 9-10 September 2013. 
23. Tang, Z.; Jayakar, K.; Feng, X.; Zhang, H.; Peng, R.X. Identifying smart city archetypes from the bottom up: A content analysis of municipal plans. Telecommun. Policy 2019, 43, 101834. [CrossRef]

24. Yamada, K. Public response to news reports on the Mount Kusatsu-Shirane volcanic eruption: A content analysis of online reader comments. Int. J. Disaster Risk Reduct. 2020, 43, 101388. [CrossRef]

25. Haas, C.; Howell, S.E. Ice thickness in the Northwest Passage. Geophys. Res. Lett. 2015, 42, 7673-7680. [CrossRef]

26. Xinhua News. The Chinese research vessel Xue Long completes its first voyage on the NSR. 2012. Available online: http://www.gov.cn/jrzg/2012-08/03/content_2197844.htm (accessed on 16 March 2020).

27. Xinhua News. Domestic sea fog visibility profiler has been used in Arctic scientific expeditions for the first time. 2018. Available online: http://www.gov.cn/xinwen/2018-07/28/content_5310114.htm (accessed on 16 March 2020).

28. Han, G. The practice and outlook of developing Arctic shipping routes by Chinese commercial vessels. World Ship. 2019, 42, 1-5. (In Chinese)

29. Arctic Council. Status on implementation of the AMSA 2009 report recommendations. 2017. Available online: https://oaarchive.arctic-council.org/handle/11374/1957 (accessed on 19 March 2020).

30. Pollution Prevention and Response Committee (PPR). Information and highlights of PPR 7th session. 2020. Available online: http://www.imo.org/en/MediaCentre/MeetingSummaries/PPR/Pages/PPR-7th-Session.aspx. (accessed on 19 March 2020).

Publisher's Note: MDPI stays neutral with regard to jurisdictional claims in published maps and institutional affiliations. 